WIDER Working Paper 2019/61

\title{
Charity begins at home
}

The political economy of non-tariff barriers to trade in Southern Africa

Tracy Ledger*

August 2019 


\begin{abstract}
Increased intra-regional trade in southern Africa will have a positive impact on economic growth. However, this requires a shifting of loyalties from the national to the regional. Tension between the goals of long-term regional development and shorter-term national imperatives remains unresolved. This study presents a review of recent and current local content regulation (LCR) initiatives across a sample of the South African Development Community countries. LCRs are widely used across these countries, and their use has increased recently. Evidence suggests that the impact of LCRs is mixed, depending on their national context, whether or not they are implemented in line with the genuine desire to deliver local development, and whether they can remain corruption-free. LCRs may have long-term positive domestic and regional benefits, if they support sustainable local enterprise development and employment. In time this should translate into higher levels of growth across the region, and thus drive higher levels of trade.
\end{abstract}

Key words: local content, regional integration, South African Development Community

JEL classification: F1, K3, L5, O2

Acknowledgements: This working paper was produced by Trade \& Industrial Policy Strategies (TIPS) for the programme Southern Africa - Towards Inclusive Economic Development (SATIED), under the work stream on Regional Growth for Southern Africa's Prosperity. TIPS acknowledges the support of the SA-TIED programme for this working paper, with special thanks to UNU-WIDER and the South African Department of Trade and Industry.

*School of Social Sciences, University of the Witwatersrand, Johannesburg, South Africa; tracymledger@gmail.com.

This study has been prepared within the UNU-WIDER project Southern Africa-Towards Inclusive Economic Development (SA-TIED)

Copyright (C) UNU-WIDER 2019

Information and requests: publications@wider.unu.edu

ISSN 1798-7237 ISBN 978-92-9256-695-1 https://doi.org/10.35188/UNU-WIDER/2019/695-1

Typescript prepared by Ayesha Chari.

The United Nations University World Institute for Development Economics Research provides economic analysis and policy advice with the aim of promoting sustainable and equitable development. The Institute began operations in 1985 in Helsinki, Finland, as the first research and training centre of the United Nations University. Today it is a unique blend of think tank, research institute, and UN agency — providing a range of services from policy advice to governments as well as freely available original research.

The Institute is funded through income from an endowment fund with additional contributions to its work programme from Finland, Sweden, and the United Kingdom as well as earmarked contributions for specific projects from a variety of donors.

Katajanokanlaituri 6 B, 00160 Helsinki, Finland

The views expressed in this paper are those of the author(s), and do not necessarily reflect the views of the Institute or the United Nations University, nor the programme/project donors. 
There is a generally held view that increased intra-regional trade in southern Africa, and the concomitant development of regional value chains across a wide range of goods and services, will have a long-term positive impact on regional economic growth. In contrast to this public discourse of regional integration, South African Development Community (SADC) intra-regional exports peaked in 2013, and then declined (Bronauer and Yoon 2018), and the previous enthusiasm for greater regional integration appears to have stalled recently (Arndt and Roberts 2018). Milestones in the establishment of a free trade area for SADC have consistently not been met. Mapuva and Muyengwa-Mapuva (2014: 25) contend that much of this disappointment can be traced back to policymakers not taking sufficient notice of 'the evident fissures within the regional grouping'.

Haas (1961: 366) defined integration as a process 'whereby political actors in several distinct national settings are persuaded to shift their loyalties, expectations and political activities toward a new centre'. This shifting of loyalties — from the national to the regional—is a critical threshold that must be crossed on the path to greater regional integration. But the tension between the goal of long-term regional development and shorter-term national imperatives around domestic employment and enterprise development does not appear close to resolution.

Value chain analysis work done to date in southern Africa (such as that on the southern African poultry value chain; see Ncube et al. 2017) has identified as one of the two most important barriers to increased regional trade narrowly defined domestic policies that protect domestic economic interests and undermine the development of integrated regional value chains. Although there is an apparent general high-level policy consensus that the growth of such value chains is an important long-term strategy in the economic development of the region, non-tariff trade barriers (NTBs) appear to be increasing, in particular the use of local content regulations (LCRs). This illustrates well the 'frequent incoherence between national policies and the regional integration agenda' that is a key factor stalling greater integration (Arndt and Roberts 2018: 300). These LCRs assume a variety of forms and are driven both by a range of motivating factors and by various actors across the public and private sectors in each country.

This study presents an initial and high-level review of recent and current LCR initiatives across a sample of SADC countries-South Africa, Namibia, Botswana, Zimbabwe, Zambia, and Tanzania. The initiatives under observation cover a wide range of policy instruments, regulation, practices, and discourse which have the effect of (or the intended effect of) privileging domestically produced goods and services over those from other countries, including (and sometimes particularly) from regional trading partners. What are the various forms that these LCRs take in the focus countries, and what are the main factors that motivate their development and implementation? What are the possibilities for reconciling these national policies with the regional integration goals of SADC?

The identification of LCRs in each country was undertaken by means of a document and media scan: the intention of the former was to identify formal policies and regulations for LCRs, while the aim of the latter was to obtain insights into the public discourse in each country around the perceived tension between regional integration and domestic economic priorities, and corresponding pressure on policymakers.

LCRs are widely used across the identified southern African countries, and their use has increased in recent years. However, many of these policies are 'informal', in that they are not accompanied 
by enforcement legislation. It is clear there are many incentives for private companies to engage in high levels of local procurement, outside of formal legislation requiring them to do so.

The crucial policy question is whether LCRs are a good or bad thing for long-term regional integration and development. There is no easy answer to this: the evidence suggests that the impact of LCRs is mixed, depending to a great deal on the national context within which they are implemented, whether they are implemented in line with the genuine desire to deliver broad-based local economic development, and whether they achieve a sustainable improvement in the number of successful local enterprises and local employment.

LCRs may in fact have long-term positive domestic and regional benefits, if they are able to support sustainable local enterprise development and employment, and thus income growth. In time this should translate into higher levels of growth across the region, and thus drive higher levels of trade across multiple categories of goods and services.

Section 2 of this paper provides an overview of the main forms that LCRs can take, as well as their global usage since the 2009 start of the global recession. Section 3 provides an overview of the current form of LCRs in each of the study countries, focusing on both formal (i.e. regulated) and informal structures that force and/or encourage the use of domestically produced goods and services over regional or global alternatives. Section 4 considers the position of LCRs in international trade obligations and governing conventions. Section 5 provides an overview of the main drivers of the use of LCRs, and Section 6 presents the main conclusions of the study.

\section{An overview of LCRs and their global usage since 2009}

An important watershed in the global usage of all forms of NTBs to protect local economies was the 2008-09 start of the global recession. The resulting protracted period of limited economic growth and rising unemployment made the use of NTBs such as LCRs significantly more popular in many countries (Hufbauer et al. 2013). LCRs are similar in many respects to quotas on imported goods, since they effectively (although not explicitly) limit the amount of goods and services sourced from foreign companies (Hufbauer et al. 2013).

This study suggests that three main features can be used to distinguish different kinds of LCRs in analysing their origins (i.e. the key factors motivating their existence), and thus the possibilities for their regulation by regional and/or international trade groupings.

The first feature is the origin of the LCR: has it been initiated (and currently enforced) by the state in question or has it been developed, implemented, and overseen by private companies?

The second is the target of the LCR: is it aimed at regulating a particular category of goods and services and/or one particular sector (such as agriculture or banking) or is it aimed at regulating the purchases of a particular group of buyers (such as supermarkets)? In practice, more than one group is the target, such as agricultural products bought by supermarkets.

The third is the formality of the LCR: does it represent a piece of formally enacted legislation, enforced by the government, or does it reflect a more informal arrangement, such as a regular call by local politicians and the media to 'buy local' as an act of economic patriotism? These differentiating features are summarized in Table 1. 
Table 1: Typology of LCRs

\begin{tabular}{ll}
\hline Feature & Characteristics \\
\hline Origin & Initiated by the state, generally with supporting legislation \\
& Initiated by private companies, without enforcing legislation \\
Target & $\begin{array}{l}\text { Particular types of goods and services } \\
\text { Particular sector(s) } \\
\text { Particular buyers }\end{array}$ \\
Formality & $\begin{array}{l}\text { Formal legislation } \\
\text { Informal pressure }\end{array}$ \\
\hline
\end{tabular}

Source: Author's compilation.

The first distinction is particularly important in southern Africa (given the central role of non-local companies in the natural resources sector, as discussed below), but is often overlooked in the analysis of NTBs, which tend to focus on formal regulation. Hufbauer et al. (2013) identified the following main forms of LCRs currently in use, which are applicable to public procurement or private sector procurement, or both, and which are based on regulation:

- mandated LCR percentages for the purchases of goods and services,

- concessions granted on local procurement (such as tax or price concessions),

- import licensing procedures that favour domestic purchases, and

- limiting certain activities to local businesses only.

State-initiated and regulated local procurement regulations can apply either to public procurement (its most common incarnation) or to procurement by the private sector. In general, public sector local procurement regulations in SADC tend to be applied across public expenditure categories (with exemptions for goods and services that are not available locally), while private sector regulations tend to be developed for specific sectors-most notably the retail and mining sectors in southern Africa - and thus impact particular buyers of specified goods rather than all the buyers of particular goods.

The definition of 'local' for the purposes of these regulations is highly variable, both across and within countries over time. In some instances, the determination of local is based on the geographical location of the supplier; in others, it is linked to the nationality of the owners of the supplier. Local procurement regulations are sometimes (but not invariably) tied to the specification of minimum local ownership in certain sectors, which—by definition—renders all the participants in that sector local.

Sometimes LCRs are applied not to a particular set of goods and services, but rather to a particular group of buyers, such as supermarkets. In these instances, the buyers are identified as key importers of items that could be procured locally, and the size of this potential procurement is deemed important enough that local procurement needs to be enforced through regulation. LCRs are also often used by countries in mega contracts that are open to global bidding, such as large infrastructure development or natural resource exploitation. In these instances, the assessment of bidders' proposals may contain a local content weighting of up to 40 per cent (Mireftekhari 2013).

However, despite the importance of state legislation and regulation in the development of LCRs, and the fact that they are most commonly manifested through public procurement, it is important to note the role of the private sector in initiating LCRs, particularly in developing countries. A considerable share of local content procurement by private companies is often driven more in developing countries by the purchasing company on its own initiative than by the response to formal prescriptive regulation by the government in question (Nickerson et al. 2017). That is, companies are implementing local procurement strategies in the absence of any legislated requirement to do so, and in many examples when it could be cheaper and/or easier to procure 
the items in question from foreign suppliers. This proactive implementation of local procurement appears to be the case particularly with large natural multi-national resource extraction corporations, operating in mining, natural gas, and oil extraction. These companies are aware of the potential for domestic opposition to 'foreigners' benefitting from the exploitation of a country's natural resources, and so have a strong focus on demonstrating that they add value to the domestic economy (Nickerson et al. 2017). The primary tool for this is through local procurement (social investments in infrastructure such as schools and healthcare facilities are usually the second-favourite option).

Most of the foreign extractive industry corporations in southern Africa have increased their local procurement spend over the past 20 years and make great use of this fact in demonstrating their commitment to their host countries. Given the size of many of these companies, their local procurement may be significant (individual country examples are discussed in more detail in Section 3). Although these practices have the effective result of discriminating against foreign goods and services, the primary motivation of the companies that engage in these practices is to entrench themselves in their host countries rather than to discriminate against foreign-produced goods and services. Much of the literature on local content tends to ignore the importance of these 'voluntary' local procurement initiatives, and as a general rule they fall outside of free trade discussions, despite the fact that they may be considerable in scope.

\section{Recent developments in the use of LCRs across southern Africa}

All of the countries under consideration have some kind of formal regulation and/or policies in place that prioritize local enterprises, although the form these take varies. Many of these policies have been implemented in the last five years, indicating the growing use of such measures. Additionally, many of these countries have seen a growing public discourse around the importance of buy local policies in domestic economic development. Much of this appears motivated by increasing political pressure on governments to demonstrate commitment to achieving higher levels of economic growth and employment, but there also appears to be a strong link between these policies and the disproportionate size of the South African economy in the regional economy. This trade imbalance is contributing to 'exacerbating political strains among (SADC) member states' (Bronauer and Yoon 2018: 5), partly manifested in more aggressive local content policies.

Many of the most recent developments in the use of LCRs in southern Africa have been in response to the rapid expansion of many South African companies-and in particular the large South African supermarket chains - into the region. The response of many countries suggests that there is little sense of a regional economy, much less the prioritization of the growth of this regional economy. Instead, it is quite clear that in many instances South African companies are viewed as 'foreign' potential threats to local economic development and employment. There is thus a considerable gap between the discourses of southern African regional integration and free trade, and political practice and public opinion.

What are the most commonly used LCRs identified in the countries included in this study?

\subsection{Botswana}

Botswana has long institutionalized preferential local procurement in public sector procurement. The government is the single biggest consumer of goods and services in the country, and all parts of government (including state-owned enterprises) are required to purchase all goods and services 
from locally based entities, as long as these are locally available, meet specifications, and are competitively priced. In 2015, a programme was introduced to give additional preferential treatment to local companies bidding for government tenders: small companies now have a 15 per cent preferential price margin, while medium and large companies have a preferential margin of 10 and 5 per cent, respectively (US State Department 2017). These discounts apply to a wide range of procured goods and services. Further, most state tenders restrict applicants to locally registered entities.

In addition, the 2003 Trade Act lists a total of 35 sectors in which participation is limited (through a licensing system) to citizens of Botswana only. The list includes butcheries, petrol stations (supermarkets-with an exception for chain stores), certain construction and manufacturing activities, bars, and fresh produce vendors. Foreigners are generally only allowed to participate in these sectors as minority partners, and not in very small enterprises, unless they obtain permission from the Minister of Trade.

The definition of 'chain store' for the purposes of this legislation has in the past been generously interpreted to include any enterprise with more than one store. This facilitated the expansion of (primarily) South African supermarket chains into Botswana. However, since 2015 the Government of Botswana has taken a more restrictive view, and (compulsory) operating licences to foreign stores are now granted on the basis of local procurement and local skills development.

Mining is the most important sector in the Botswana economy, and in 2014 the government and the Chamber of Mines instituted a programme whereby mining companies committed to purchasing 10 per cent of mining supplies from local enterprises. De Beers has reported that almost 90 per cent of its expenditure in Botswana is with local companies (Nickerson et al. 2017), considerably in excess of these requirements.

\subsection{Namibia}

There has been a growing focus on LCRs in Namibia over the past few years, so much so that the country's 2015 industrialization strategy is entitled 'Growth at Home' and has a core focus on preferential local procurement across the economy. A scan of Namibian media over the past five years indicates many occasions when senior government officials have identified local procurement as a critical strategy to support the local manufacturing sector and to grow the economy.

However, formal regulation of this is limited to public sector procurement. The new Public Procurement Act (PPA) of 2015 came into effect on 1 April 2017. The PPA regulates all procurement by the state, including by state-owned enterprises. The PPA has as one of its clear goals the promotion of locally produced goods and services. Public entities may restrict tenders to local bidders only and may impose an additional restriction limiting participation to companies that have a minimum 30 per cent ownership by previously disadvantaged groups.

There are two main focus areas regarding the procurement practices of private companies. The first is the retail sector, including supermarkets. The 2016 Namibian Retail Sector Charter (which is a voluntary charter) has as one of its core goals the promotion of local manufacturing, and thus includes a local sourcing provision. Part 4 of the charter lists one of its objectives as 'to support local businesses in securing retail space at home, so as to increase the visibility of their products through the promotion, marketing and distribution of such products'. The charter makes provisions not only for targets for local procurement but also for retailers to market Namibian products more aggressively (there is a marketing budget target included), and to allocate such products more and better shelf space. Although the charter is voluntary, the Namibian government monitors compliance, and most foreign retailers (notably, South African companies) appear to be 
adopting the view that non-compliance is to be avoided. Retailers are sensitive to public opinion and generally do not want to be seen to be undermining local economic development strategies in their host country.

The mining sector is an important part of the Namibian economy, with De Beers (diamond mining) the most visible participant. Once again, there is no formal regulation (enforcement) of local procurement by the mining sector, but instead a voluntary charter. The charter sets out targets for local procurement, and companies submit annual reports detailing whether (or why not) they have met these targets. In recent years, the charter targets have been supplemented by targets for purchases from companies owned by historically disadvantaged Namibians. Compliance is also voluntary, although the government requires comprehensive compliance reporting (Nickerson et al. 2017).

Despite the voluntary nature of compliance with the mining charter's local procurement regulations, mining companies like De Beers appear to be making a considerable effort to exceed the charter's targets and publicly to demonstrate that they are 'good Namibian citizens'.

\subsection{South Africa}

South Africa has been described as being 'among the most vigorous users of NTBs in the world' (Drope 2007). The country has a strong effective local procurement incentive environment operating through public sector procurement regulations (which trickle down through the private sector via primary suppliers and which require compliance from their suppliers to maximize the points they can be allocated under these preferential procurement requirements) and via various sector charters. However, the focus of the South African LCR system is not on all local procurement, but rather local procurement from previously disadvantaged individuals. BroadBased Black Economic Empowerment (BBBEE) policies and regulation have the effect of putting certain categories of local suppliers in a preferential position through the weighting of BBBEE participation levels in suppliers (as well as some additional preferential treatment for small and medium enterprises). Companies receive a BBBEE score on the basis of their performance in a number of categories, including ownership, employment profile, and their own procurement practices. There are no formal restrictions, however, on participation in the economy, and generally no restrictions on who may submit a tender for government contracts. Rather, the system allocates more points to bidders that have a higher BBBEE score, thereby giving them an advantage over other local or foreign bidders.

The pressure for BBBEE procurement in the private sector comes via particular sector charterssuch as the mining charter-and/or through companies that wish to bid for government work pushing up their BBBEE score by increasing their own procurement from companies that themselves have a high BBBEE score. Compliance with BBBEE targets varies enormously throughout the economy, with the highest levels seen in the public sector as well as companies that are dependent on the government for their operating licences (such as mining). In other sectors — such as retail—which have little such incentive, compliance levels are much lower. One of the criticisms of this system is that BBBEE-compliant companies may have a majority local ownership, but their main business is to import goods that are then sold on. In some cases, this system has given preference to compliant BBBEE firms who are importers over non-compliant BBBEE firms who are local producers.

To overcome this challenge, and to ensure greater support for local production, in 2017 amended regulations were issued for public sector procurement. These empowered the South African Department of Trade and Industry both to stipulate a certain minimum threshold for local production and content and to designate certain products for which all or most of the public sector 
procurement must be limited to local companies only. Currently, 23 products have designated status, including clothing, certain furniture categories, and bus bodies. The selection of designated sectors has often been those under significant pressure from imports and/or to protect sector employment. However, departments may apply for exemptions and when granted this has undermined the effectiveness of the designations.

South Africa's Renewable Energy Independent Power Projects Procurement Programme includes a considerable 'non-price' component in the assessment of bids for power generation licences, focusing on local content requirements for employment and procurement (Leigland and Eberhard 2018).

A further South African initiative is Proudly South African, which was established in 2001 initially as a marketing campaign and has a mandate to encourage and promote local procurement in the public and private sectors, including among consumers. Rather than legislative, its efforts consist mainly in broad advertising campaigns to encourage 'buy local', and the certification of products and services as Proudly South African based on a minimum local content, together with adherence to labour and environmental standards. In 2011, a range of government, business, and labour representatives signed a Local Procurement Accord, which purported to support the local manufacturing sector by prioritizing local procurement. Despite these initiatives, a brief media scan suggests that the general public sentiment in South Africa is not as strongly supportive of enforcing local procurement as it appears to be in other regional economies.

\subsection{Tanzania}

Tanzania has extensive LCRs: there are restrictions on foreign investment in certain sectors (including banking, financial services, mining, and telecommunications), with minimum shareholding requirements for Tanzanian nationals in these sectors. This effectively means that only local companies may participate in these sectors. These regulations are further enforced by supporting legislation, such as that which requires that resident businesses may use only local insurance companies (which in turn must have a minimum two thirds local shareholding).

Local content policies for the gas and petroleum sectors were adopted in 2014, after the discovery of large offshore gas reserves. The country has also recently (in 2018) introduced comprehensive local procurement regulations for the mining sector. A narrow definition of a local company has been adopted. An indigenous Tanzanian company means a company incorporated under the Companies Act of Tanzania with at least 51 per cent owned by Tanzanian citizens, Tanzanian citizens holding at least 80 per cent of the executive and senior management positions, and Tanzanians occupying 100 per cent of non-managerial and other positions. Designated Tanzanian companies are given first preference in the allocation of mining licences.

The LCRs in Tanzania also make specific provision for mining companies to allocate funds to education, skills transfer, and enterprise development in order to maximize local procurement and employment. The LCRs are implemented by a Local Content Committee (which falls under the authority of the Mining Commission), whose function is to oversee the implementation of LCRs, set targets, and monitor compliance. All companies in the mining sector are required to submit local content plans to the committee. A range of (high) targets have been set in the regulationcovering both procurement and staffing over a 10 -year period and containing considerable detail across the various procurement and staffing categories (Government of Tanzania 2018).

The new LCRs were described in certain Tanzanian media as an 'honourable and bold initiative' (The Exchange 2018), reflecting a general sentiment in the country that extractive industries have in 
the past made little positive impact on the lives of ordinary Tanzanians and a change in the way things are done is supported.

It is also important to note that, although this is not generally classified as an LCR, foreigners may only access land in Tanzania in terms of a lease granted by government. This may have the impact of effectively reserving certain land-intensive activities for local entities.

\subsection{Zambia}

Zambia has the lowest level of LCRs in the group of countries under review. The country has seen significant expansion of South African supermarket chains over the past 10 years, with a concomitant sharp increase in manufactured goods from South Africa to stock these stores (Ziba and Phiri 2017). Together with high levels of foreign ownership in the mining sector, against a low level (5 per cent) of local procurement by mines (Kumi Consulting 2015), this has increased popular calls for Zambia to move 'in line' with other African states in implementing local content and ownership legislation.

In September 2018, the Zambian Minister of Finance announced that the government would be implementing a National Local Content Strategy 'to promote use of at least 35 per cent locally available inputs in industrial processes' (Government of Zambia 2018). Apart from this legislative move, it appears that the same informal pressures to demonstrate commitment to the local economy are being felt by foreign supermarkets in Zambia as in other countries. A media scan indicated SPAR supermarkets using its local purchases (reportedly 70 per cent of all products the company sells in Zambia) as a key marketing strategy.

\subsection{Zimbabwe}

Zimbabwe has followed a slightly different approach to many other SADC countries in local content legislation: historically, the country has had restrictive legislation for foreign ownership of certain categories of business and land, as well as 'reserved' sectors, but no specific local content procurement legislation. The Indigenisation and Economic Empowerment Act was legislated in 2008 and aimed to transfer 51 per cent of all businesses operating in Zimbabwe to 'indigenous' Zimbabweans. The Act never achieved all its goals, and in 2018 the new government amended it, retaining the 51 per cent ownership requirement only for diamond and platinum mining companies (and the reserved sectors, discussed below).

The original Indigenisation and Economic Empowerment Act stipulated a large number of 'reserved sectors' in which foreign businesses were prohibited from operating. Once again, this provision was never fully enforced and in 2018 these provisions were amended. There are now 12 reserved sectors (including wholesale and retail trade) in which only a business majority-owned by a Zimbabwean citizen may operate. However, existing foreign operators are permitted to continue operating, subject to registration and other requirements. Therefore, the restriction applies to new businesses.

The reservation of sectors de facto supports a certain measure of local procurement, but media reports suggest that the Zimbabwean government is finalizing a local content policy. An informal policy is currently in place, via Buy Zimbabwe, part of the Local Content project under the Confederation of Zimbabwe Industries. 
Is this general trend of increasing use of LCRs compatible with these countries' international free trade commitments and obligations? Although LCRs may have an effect that is similar to that of trade quotas, they are often perceived very differently in terms of international trade regimes and commitments under these agreements. This further increases their appeal to governments.

LCRs fall under the World Trade Organization (WTO) category of Trade Related Investment Measures (Mireftekhari 2013). However, most LCRs linked to public sector procurement are not in violation of WTO agreements ${ }^{1}$ unless there has been a specific commitment that the sector in question would be opened to international trade. Therefore, there is generally no sanction for a government that introduces LCRs for public procurement. However, this may not be the case with legislation that regulates private sector procurement, but the enforcement of this is problematic (Mireftekhari 2013), particularly when the regulations in question — such as the various charters in Namibia-are not mandatory, but rather operate through non-regulatory incentives (such as the desire of companies to be perceived as acting in the best interests of the local economy). Most companies appear to accept LCRs as the cost of doing business in a foreign country rather than viewing them as undermining free trade. A further challenge is that only WTO member governments are entitled to register a complaint with the WTO (Hufbauer et al. 2013), not an individual company which believes that it is being disadvantaged by LCRs. In practice, member governments will bring such a complaint only when the size of a lost export market due to new LCRs is considerable, and there is no downside, such as negative customer sentiment.

The dividing line between 'traditional' NTBs_ such as quota restrictions on imported goodsand policy measures such as LCRs is far from clear cut, even when LCRs are driven by legislation rather than individual company discretion. Although there are many policy and regulatory instruments that may have the effect of discriminating against foreign-produced goods and services, not all of these measures have such discrimination as their primary motivation. One good example is South Africa's public sector preferential procurement legislation (BBBEE), which is intended to benefit a range of previously disadvantaged citizens through a scoring system that rewards companies with higher levels of ownership, employment, and/or procurement from such citizens. This legislation-focused on public sector procurement-has had a knock-on effect on procurement throughout the private sector, since companies that wish to bid for public sector work need to show that they themselves are procuring from entities that have high BBBEE scores.

One of the results of South Africa's BBBEE regulations is thus to discriminate against foreignowned suppliers of goods and services, but it was not designed primarily as an NTB as it does not discriminate against foreign goods. This blurred dividing line between policies that aim to redress historical inequalities in access to economic opportunities-an important driver of much economic regulation in most of the former colonies that make up contemporary southern Africaand those that are genuinely motivated by the desire to limit market access for foreign goods and services creates challenges for promoting greater regional trade. Where is the dividing line between policies and practices that are deemed a legitimate part of international trade negotiations and those that are seen as the exclusive preserve of domestic economic policy? These are key questions that need to be addressed to improve the coherence between national development strategies and the long-term goals of greater free trade and regional integration in southern Africa.

\footnotetext{
1 The Government Procurement Agreement.
} 
As discussed, LCRs may be initiated or supported by the state (formally or informally) or by individual companies. Over the past 10 years, the dominant motivator of the increased use of LCRs by states has been to support increased employment and income 'at home' rather than in other countries. The rising use of LCRs can thus be seen as part of the general global decline in enthusiasm for globalization, which is increasingly portrayed as having only a few country winners and many losers. The election of right-wing governments across the world reflects a growing preoccupation with prioritizing domestic national requirements over global ones, and this is reflected in economic policies. The current political climate of increased economic nationalism is also pushing the adoption of local procurement strategies by foreign companies keen to avoid the label of 'foreign'.

'Infant industry' arguments are often advanced in support of LCRs, particularly when the country is entering new sectors (high technology and renewable energy are common candidates) or when there is a perceived threat to an existing industry from regional trade. One of the attractions of the use of LCRs for governments is that they do not have a direct fiscal implication (apart, perhaps, from compliance and enforcement costs) and thus represent a relatively cheap means of stimulating local employment and enterprise development.

Structural economic constraints may inadvertently contribute to-or give rise to-greater levels of local procurement. In contemporary Zimbabwe, local procurement is effectively enforced by the extreme shortage of foreign exchange which makes payment for foreign goods and services difficult and lengthy. In this example, local procurement is the only viable option for domestic buyers.

A significant portion of intra-SADC trade can be attributed to increased exports of goods and services from South Africa to other SADC members. South Africa contributes more than two thirds of the exports in intra-SADC trade (Bronauer and Yoon 2018). The main products exported from South Africa to other SADC countries are machinery and equipment and food products (Arndt and Roberts 2018). Exports of machinery and equipment (driven primarily by mining and other extractive industries) have declined sharply since 2012, reflecting the global decline in commodity prices. Food exports have been much more resilient and have recorded only a small decline since 2014 (Arndt and Roberts 2018).

Food exports from South Africa have been driven to a considerable degree by the expansion of South African retailers (particularly supermarkets) among other sectors into the region. It is notable that these retail companies have historically sourced the majority of their stock from South Africa, despite high transport costs, because of the low level of availability of many items in other countries and existing supplier relationships. The resulting trade imbalance, together with perceptions that South African supermarkets are unfairly stocking 'foreign' goods that are available locally, has been a key driver of the use of LCRs across SADC countries in the retail space. This has been particularly evident with fresh produce and minimally processed items, such as poultry.

The resulting discourse has great appeal: 'We (i.e. the citizens of the country in question) are spending our money at the South African supermarkets, and in return they must buy from us.' It is an attractive proposition for local politicians to push greater local procurement by South African supermarkets, since this represents a cost-free local job and enterprise-creation strategy (i.e. the 'cost' of this is carried by the company in question). In turn, South African supermarkets are understandably wary of losing business if they are perceived as foreigners hostile to local economic development. South African supermarkets may not, in fact, be responsible for importing more 
food items into SADC countries than that which arrives from China or other countries, but they are very visible to citizens in a way that these other products are not (particularly if they are then sold by local businesses). The point is that the supermarket is the primary target of these buy local campaigns rather than the specific items that they stock on their shelves.

\section{Conclusion}

LCRs are widely used across the identified southern African countries and their use has increased in recent years. However, it is interesting to note how many of these policies are informal, in that they are not accompanied by legislation to enforce them (such as the various voluntary sector charters). Despite this lack of enforcement, most private companies-particularly large multinationals-are making a considerable effort to comply, often exceeding the voluntary targets. This makes it clear that there are many incentives for these companies to engage in high levels of local procurement, outside of formal legislative enforcement mechanisms. These other incentives may act as an effective barrier to greater regional trade, but they are almost impossible to regulate.

Many of these initiatives do not have limiting foreign imports of goods and services as their primary motivations. Instead, they are aimed (ostensibly) at supporting local job creation and enterprise development. It is a hard sell for political leaders to defer these immediate visible positive benefits for possibly greater longer-term benefits that may accrue from greater regional integration and the development of regional value chains. Herghelegiu (2017) also concludes that economic and political factors are important for developing countries when implementing NTBs.

The brief country reviews clearly show that several factors are creating pressure on private companies to prioritize local procurement, apart from formal regulation. This is well illustrated in Namibia, which has no enforceable formal regulation of local procurement outside of the government sector, but where 'voluntary' charters have put considerable pressure on companies to source products locally.

The critical policy question is whether LCRs are a good or bad thing for long-term regional integration and development. There is no easy answer to this: the evidence suggests that the impact of LCRs is mixed, depending to a great deal on the national context within which they are implemented, whether they are implemented in line with the genuine desire to deliver broad-based local economic development, and whether they achieve a sustainable improvement in the number of successful local enterprises and local employment. This last point-the 'effectiveness' of LCRs in actually supporting local economic development-is particularly important but remains largely unanswered in an empirically robust manner. A better understanding of exactly how well LCRs are working would provide the foundation for an informed discussion around the trade-offs between regional integration and local development imperatives.

The relationship between developing and growing regional value chains, and increased regional economic development is complex, and not unidirectional (i.e. from growing value chains to growing economies) in causality, although it is often presented in this manner. Instead, it is a circle of mutually reinforcing benefits (or losses): local procurement-particularly by the public sectormay contribute to increased economic growth and enterprise development that in turn facilitates greater regional trade (by creating a larger pool of potential regional suppliers and customers), thus growing regional value chains. However, such policies may also stifle opportunities for regional value chain development, reducing long-term economic growth potential. The critical challenge is how to achieve a balance that will accommodate domestic imperatives within a longer-term trajectory of regional value chain growth. 
Although LCRs may be implemented with laudable goals, they may have undesirable outcomes (Hufbauer et al. 2013). They may, in fact, undermine local development goals by increasing the costs of procurement, and the time required to complete such procurement, particularly when the procurement in question is related to the development of productive infrastructure. They are by their nature also vulnerable to corruption and political favouritism that may undermine their developmental goals. Kinyondo and Villanger's (2016) review of local content policies in Tanzania's natural gas sector indicated that while most Tanzanian companies were in favour of such policies, they also voiced a high level of concern that the implementation of these policies would be subject to high levels of corruption that could dilute their impact.

In addition, if the local economy in question is not developed enough to take full advantage of LCRs then these measures may be counter-productive (Benin 2017), although they may also act as an incentive for companies to invest in supplier development (Osstenson 2017) which has generally positive long-term impacts.

It is difficult, however, to regulate the use of domestic LCRs at a regional level, particularly in the current circumstances in which one economy (South Africa) is generally viewed as a domineering big brother with the potential to stifle business opportunities in neighbouring countries. This regional imbalance (actual and perceived) undermines political unity around long-term goals for regional integration. It is even more difficult to regulate when so many of the initiatives are being undertaken through corporate initiatives, without a regulatory impediment.

Despite these possible shortcomings, LCRs may have long-term positive domestic and regional benefits, if they are able to support sustainable local enterprise development and employment, and thus income growth. In time this should translate into higher levels of growth across the region, and thus drive higher levels of trade across multiple categories of goods and services.

It is important to note that a preferential view of domestic suppliers is never entirely eradicated by a regional free trade agreement. Even in the European Union (EU) - the most integrated of all regional trade arrangements - the practices of informally promoting locally produced goods and services over their foreign alternatives (i.e. from other EU countries) persist, although to different degrees across member countries and driven by different socio-economic factors. France is a good example: the country has a strong history of preferring domestically produced products, generally based on a deeply held belief of the superiority of these products, together with strong cultural preferences, particularly with food. These preferences are used to good measure by French companies: all supermarkets have clearly demarcated sections where only products produced in France are on sale, and these are clearly differentiated from those originating in other EU countries. Most restaurants use as a selling point the French-only provenance of most of their menus. Many non-French cars carry permanent stickers from their manufacturers identifying the vehicle as 'made in France', to encourage potential buyers. The distinction in this case between 'made in France' and 'made in the EU' is clear, as is its intention.

Regional trade policies need to recognize and integrate the local drivers and political imperatives that lie behind regulations and informal strategies that aim to give preferential market access to domestic enterprises. The relative size of the South African economy and the regional dominance of South African companies in certain sectors-most notably, the retail sector-need to be acknowledged in regional value chain development strategies. In the longer term, the development of robust domestic economies in each of the SADC countries can benefit all market participants, but only if domestic enterprise development strategies include regional value chain development and participation as clear long-term goals alongside short-term goals of local procurement. 
One policy option is to focus on the development of deeper and more complex intra-regional value chain linkages among firms across different countries, with a clear focus on equitable sharing of value chain benefits among various country participants (Arndt and Roberts 2018). These firmbased value chain linkages would focus, inter alia, on building capacity across all regional economies to take advantage of local procurement regulations. The fact is that SADC trade is currently primarily with global markets — rather than intra-regional (Bronauer and Yoon 2018)which implies that there is significant potential for greater regional trade. However, until all member states are satisfied that the benefits of such trade will be more equitably shared, domestic resistance to the regional development agenda will remain.

Another policy option would be to develop a regional approach to LCRs, with a long-term strategy informed by the goal of developing more equitable intra-regional value chains, supported by sustainable local businesses (with critical operating mass) in each participating country. This could facilitate the growth of larger competitive regional firms which would then be in a better position to enter global markets.

\section{References}

Arndt, C., and S.J. Roberts (2018). 'Key Issues in Regional Growth and Integration in Southern Africa'. Development Southern Africa, 35(3): 297-314.

Benin, P. (2017). 'Human Resource Local Content in Ghana's Upstream Petroleum Industry'. Unpublished PhD Thesis. Minneapolis: Walden University.

Bronauer, J., and J. Yoon (2018). 'Regional Economic Development in SADC: Taking Stock and Looking Ahead'. Report 25. Johannesburg: South African Institute of International Affairs.

Drope, J.M. (2007). 'The Political Economy of Nontariff Trade Barriers in Emerging Economies'. Political Research Quarterly, 60(3): 401-14.

Government of Tanzania (2018). 'The Mining (Local Content) Regulations'. Government Notice 3, 10/01/2018. Government of Tanzania.

Government of Zambia (2018). National Local Content Strategy, 2018-2021. Ministry of Commerce, Trade and Industry, Government of Zambia.

Haas, E.B. (1961). 'International Integration: The European and the Universal Process'. International Organization, 15(3): 366-92.

Herghelegiu, C. (2017). 'The Political Economy of Non-tariff Measures'. G-MonD Working Paper 47. Paris: Paris School of Economics.

Hufbauer, G.C., J.J. Schott, C. Cimono-Issacs, M. Vieiro, and E. Wada (2013). 'Local Content Requirements: A Global Problem.' Washington DC: Peterson Institute for International Economics.

Kinyondo, A., and E. Villanger (2016). 'Local Content Requirements in the Petroleum Sector in Tanzania: A Thorny Road from Inception to Implementation?’ CMI Working Paper WP 2016: 6. Bergen: Chr. Michelsen Institute.

Kumi Consulting (2015). 'Strengthening Local Procurement in the Zambian Copperbelt'. London: Kumi Consulting Ltd.

Leigland, J., and A. Eberhard (2018). 'Localisation Barriers to Trade: The Case of South Africa's Renewable Energy Independent Power Programme'. Development Southern Africa, 35(4): 569_ 88. 
Mapuva, J., and L. Muyengwa-Mapuva (2014). 'The SADC Regional Bloc: What Challenges and Prospects for Regional Integration?'. Law, Democracy and Development, 18: 22-36.

Mireftekhari, S. (2013). 'Local Content Management in Global Oil and Gas Projects'. Unpublished Master's thesis. Norway: Norwegian University of Science and Technology.

Ncube, P., S. Roberts, and T. Zengeni (2017). 'The Southern African Poultry Value Chain: Regional Development versus National Imperatives'. WIDER Working Paper 2017/97. Helsinki: UNU-WIDER.

Nickerson, E., J. Geipel, and H. James (2017). 'The Relationship between Local Procurement Strategies of Mining Companies and their Regulatory Environments. A Comparison of South Africa and Namibia'. Mining Shared Value and Canadian International Resources and Development Institute.

Osstenson, O. (2017). 'Local Content, Supply Chains, and Shared Infrastructure'. WIDER Working Paper 2017/96. Helsinki: UNU-WIDER.

The Exchange (2018). 'Local Content Regulations in Mining in Tanzania'. Available at: https://www.exchange.co.tz/local-content-in-tanzanias-mining-sector-and-its-compliancewith-the-wto/local-content-regulations-in-mining-in-tanzania-the-exchange/ (accessed 14 January 2019).

US State Department (2017). 'Botswana Country Commercial Guide: Botswana-Foreign Investment 18 July 2017'. Washington DC: Office of Investment Affairs, US State Department.

Ziba, F., and M. Phiri (2017). 'The Expansion of Regional Supermarket Chains: Implications for Local Suppliers in Zambia'. WIDER Working paper 2017/58. Helsinki: UNU-WIDER. 